\title{
DETEKSI DINI KANKER SERVIK PADA WANITA USIA SUBUR DENGAN INSPEKSI VISUAL ASAM ASETAT (IVA TEST) DI KLINIK BERSALIN KOTA MEDAN
}

\author{
Diah Lestari Nasution ${ }^{1)}$, Nur Asnah Sitohang ${ }^{2)}$, Cut Adeya Adela ${ }^{3)}$ \\ 1) Fakultas Keperawatan, Universitas Sumatera Utara \\ Email: diah.lestari@usu.ac.id \\ 2) Fakultas Keperawatan, Universitas Sumatera Utara \\ Email: nur75asnah@yahoo.co.id \\ ${ }^{3)}$ Fakultas Kedokteran, Universitas Sumatera Utara \\ Email: adeya_adella@yahoo.com
}

\begin{abstract}
Abstrak
Kanker rahim di Indonesia menduduki peringkat pertama, 65\%. Kondisi pasiennya dalam stadium lanjut. Pada penelitian di tiga belas laboratorium patologi anatomi didapatkan jumlah penderita kanker serviks sekitar $18,5 \%$. Ditemukan sejak umur 25-34 tahun dengan puncaknya terbanyak berada pada umur 45-54 tahun. Data di RS.H.Adam Malik Medan tahun 2011 ditemukan jumlah pasien kanker serviks sebanyak 367 orang. Keluhan utama yang paling banyak dialami penderita adalah perdarahan pervaginam (77,9\%), sedangkan stadium terbanyak adalah IIIb (39,5\%). Pengabdian kepada masyarakat ini ini bertujuan untuk memberikan komunikasi,edukasi dan informasi (KIE) kanker serviks dan melakukan deteksi dini gejala kanker servik pada wanita usia subur untuk menurunkan morbiditas dan mortalitas dan memotivasi melakukan pemeriksaan IVA Test sekali dalam 3 tahun. Pengabdian masyarakat ini dilaksanakan di dua (2) Klinik bersalin yaitu rumah bersalin SAM (20 orang) dan Klinik Bersalin Sari (20 orang). Metode pendekatan yang dilaksanakan menggunakan komunikasi informasi edukasi (KIE) dan pemeriksaan serviks dengan metode IVA test. Metode analisis data menggunakan dependent $t$ test. Hasil kegiatan diperoleh data mayoritas WUS berusia 26-30 tahun (40\%),suku batak (13\%),agama islam (95\%), menikah pertama kali (77.5\%),pendidikan SMA/diploma/sarjana (80\%),IRT (77.5\%),pekerjaan suami karyawan (52.5\%), umur pertama menikah 26-30 tahun(40\%) dan tidak merokok (80 \%);menggunakan alat kontrasepsi suntik (42.5\%);riwayat obstetri mayoritas WUS melahirkan 2 kali (42.5\%),tidak pernah periksa (80\%),tidak ada saudara yang sakit(75\%),kanker payudara (10\%),tidak banyak keputihan (65\%),tidak ada sakit di bawah perut(70\%), tidak ada perdarahan saat bersenggama $(90 \%)$ dan tidak mengalami haid tidak teratur (55\%); hasil IVA Test WUS adalah negatif (80\%),radang (17,5\%) dan positif (2.5\%);pengetahuan WUS sebelum diberi Komunikasi Edukasi Informasi (KIE) tentang kanker serviks dan IVA Test rata - rata $=13.58, \mathrm{SD}=3.012$ dan sesudah diberi KIE rata - rata $=14.30, \mathrm{SD}=3.275$. Hasil uji statistik diperoleh beda mean $=0.725$ dan nilai $\mathrm{P}=0,016$, maka dapat disimpulkan ada pengaruh yang signifikan KIE terhadap pengetahuan WUS tentang kanker serviks dan IVA Test.
\end{abstract}

Kata Kunci: kanker serviks, Wanita Usia Subur (WUS), IVA Test

\section{PENDAHULUAN}

Kanker serviks merupakan kanker kedua tersering yang diderita oleh wanita di seluruh dunia. Di Amerika serikat terdapat kurang lebih 14.000 kasus baru dan terdapat 5000 kematian setiap tahun akibat kanker serviks (Azis. 2004) terdapat kurang lebih 468.000 kasus baru dimana 80\% dari kasus tersebut terdapat di Negara berkembang. Rerata kejadian kanker serviks bervariasi dan bergantung pada lokasi geografis tertentu, sepert insiden tertinggi terdapat di Amerika latin, Sub Sahara Afrika dan Asia Selatan, dan Asia Tenggara. Menurut data dari World Health Organization(WHO) diperkirakan pada tahun 2000, di seluruh dunia terdapat 6,25 
juta kanker baru pertahun dan dalam 10 tahun mendatang diperkirakan terjadi 9 jutakematian akibat kanker, dimana sebagian besar terjadi di negara berkembang.

Menurut data Kementerian Kesehatan Republik Indonesia 1989, insiden kanker serviks di Indonesia adalah sebesar 90-100 per 100.000 penduduk dan kanker serviks dikatakan sebagai kanker yang paling sering terjadi pada wanita.Berdasarkan data Riset Kesehatan Dasar (RISKESDA), badan Litbangkes (KEMENKES RI, 2013) menyebutkan prevalensi tertinggi kanker di Indonesia yaitu kanker serviks yaitu 0,8\%.Di Indonesia kanker rahim menduduki peringkat pertama, $65 \%$ kondisi pasiennya dalam stadium lanjut. Pada penelitian di tiga belas laboratorium patologi anatomi di Indonesia didapatkan frekuensi penderita kanker serviks sekitar 18,5\%. Ditemukan sejak umur 25-34 tahun dengan puncaknya terbanyak jumlah penderita berada pada umur 45-54 tahun. Sedangkan data patologi dari RumahSakit Dr. Cipto Mangunkusumo pada tahun 1998 menunjukkan $39,5 \%$ wanita menderita kanker serviks, $60 \%$ diantaranya telah pada stadium lanjut atau pada stadium II-III (Ropitasari.dkk.2014.).Penelitian yang dilakukan Prandana (2011) di RS.H.Adam Malik Medan ditemukan jumlah pasien kanker serviks sebanyak 367 orang. Menurut umur yang paling banyak adalah golongan umur 40-55 tahun (58,3\%). Seluruh penderita berstatus kawin (100\%). Kebanyakan penderita kanker serviks dengan status pendidikan SMP-SMA $(57,2 \%)$. Menurut paritas yang paling sering adalah 3-5 anak $(56,1 \%)$. Keluhan utama yang paling banyak dialami penderita adalah perdarahan pervaginam $(77,9 \%)$, sedangkan stadium terbanyak adalah IIIb (39,5\%).

Mortalitas kanker seviks di Indonesia masih tinggi. Laporan dari beberapa rumah sakit di Indonesia didapatkan angka harapan hidup tiga tahun hanya $23,5 \%$. Hal ini di karenakan 80-90 \% kanker serviks terdiagnosis pada stadium lanjut, bahkan pada stadium terminal. Dewasa ini telah diakui bahwa faktor risiko utama kanker serviks adalah infeksiHuman Papilloma Virus (HPV) tipe onkogenik yang persisten yaitu $\pm 72,3 \%$ dapat diisolasi HPV tipe 16 dan 18.Ditemukannya HPV dianggap sebagai promotor dan mungkin inisiator, sedangkan faktor risiko lainnya sebagai inisiator. Manifestasi klinik dari proses molekuler dan seluler adalah metaplasia dan displasia dimana hal ini dapat terdeteksi dengan pemeriksaan sitologis dari bahan Pap smear maupun dengan pemeriksaan histopatologis dari bahan biopsi serviks. Pemeriksaan skrining kanker serviks dengan caraInspeksi Visual dengan Asam Asetat. Metode IVA lebih sederhana, sehingga skrining mudah dilakukan dengan cakupan lebih luas dan diharapkan temuan kanker serviks dini akan bisa lebih banyak di temukan. Ideal dan optimal pemeriksaan IVA test dilakukan setiap 3 tahun pada wanita usia 25-60 tahun.

Namun, dalam pelaksanaannya metode ini masih mengalami kendala seperti keengganan para perempuan diperiksa karena malu. Penyebab lain seperti keraguan akan pentingnya pemeriksaan, kurangnya pengetahuan, serta ketakutan merasa sakit pada saat pemeriksaan. Selain hal-hal tersebut, masalah kerepotan, keraguan akanpentingnya pemeriksaan, takut terhadap kenyataan hasil pemeriksaan yang akan dihadapi, ketakutan merasa sakit pada pemeriksaan, rasa segan diperiksa oleh dokter pria atau pun bidan dan kurangnya dorongan keluarga terutama suami (8). Banyak masalah yang berkaitan dengan pasien dapat dihilangkan melalui pendidikan terhadap pasien dan hubungan yang baik antara dokter atau bidan (Ropitasari.dkk.2014).Hasil penelitian menunjukkan bahwa dari 135 responden, pengetahuan responden mayoritas rendah sebanyak 114 responden (84.4\%) (Rahmadayani.2015). 
Apabila hasil pemeriksaan papsmear atau IVA test positif, yaitu terdapat sel-sel yang tidak normal, sebaiknya segera dikonsultasikan kepada petugas kesehatan untuk dilakukan pemeriksaan dan pengobatan lebih lanjut oleh ahli kandungan. Sebenarnya penyakit ini bisa sembuh saat stadium awal.Kurangnya sosialisasi penyakit ini mengakibatkan keterlambatan penanganan.

\subsection{Permasalahan Mitra}

Program Kemitraan Masyarakat yang akan kami laksanakan ini mempunyai dua mitra yaitu rumah Bersalin SAM.Kelurahan Pasar Senen.Kec.Medan Kota (mitra1) dan Klinik Bersali Sari.Kel.Teladan Barat.Kec.Medan Kota (Mitra 2). Berdasarkan pengamatan dan wawancara kepada mitramereka menyatakan permasalahnnya sebagai berikut:

- Di Indonesia kanker serviks menduduki peringkat pertama, 65\% kondisi pasiennya dalam stadium lanjut - pengetahuan wanita usia subur tentang kanker serviks masih rendah

- pada kedua mitra belum pernah dilakukan IVA Test karena tidak ada klien yang datang untuk dilakukan pemeriksaan.

- Upaya sosialisasi kanker serviks dan pentingnya dilakukan deteksi dini dengan IVA Test juga belum pernah dilakukan

\section{SOLUSI}

Banyaknya kematian penderita kanker serviks diakibatkan karena terlambat ditemukan dan terlambat untuk diobati, walaupun sebenarnya perjalanan penyakit ini tidak terjadi secara cepat, tetapi akan semakin parah dalam hitungan tahun. Dari kondisi wanita normal ke penyakit pra kanker memerlukan waktu 5 tahun, sedangkan pra kanker ke kanker ringan memerlukan waktu 5tahun dan dari kanker ringan ke kanker sedang perlu waktu 3 tahun. Melihat dari perjalanan penyakit ini, sebenarnya bila dikenali sejak awal maka akan mempunyai prognosa yang baik, yaitu dapat disembuhkan.Pendeteksian secara dini terhadap penyakit ini dilakukan melalui pemeriksaan IVAtest maupun pemeriksaan lanjutan melalui PAP SMEAR. Metode pemeriksaan IVA test merupakan suatu metode pemeriksaan kanker leher rahim secara murah dan mudah dikerjakan, tetapi juga mempunyai akurasi hasil yang tinggi .

Tes IVA merupakan suatu metode pemeriksaan inspeksivisual yang dilakukan pada vagina dengan cairan asam asetat melalui usap serviks dengan asam cuka 3-5\% . Prosedur pemeriksaan test IVA tidak menimbulkan rasa sakit. Pemeriksaan ini menghasilkan akurasi sensitifitas dan spesifisitas yang tinggi dengan biaya sangat murah.Selain murah, pelaksanaan test IVA dilaksanakan secara masal dengan hasil cepat dan mendidik masyarakat. Metode Inspeksi Visual dengan Asam Asetat (IVA), merupakan metode screening yang lebih praktis,murah, dan memungkinkan dilakukan di Indonesia.

Keuntungan dari pemeriksaan test IVA, yaitu: 1). hasil segera diketahui;2). efektif, aman, dan praktis, 3).teknik pemeriksaan sederhana, 4).bahan dan alat yang sederhana dan murah; 5). sensivitas dan spesifikasitas cukup tinggi; 6). dapat dilakukan oleh semua tenaga medis terlatih (Ropitasari.2014).

\section{METODE PELAKSANAAN}

Berdasarkan permasalahan yang telah dikemukakan, maka dalam kegiatan ini metode yang digunakan adalah dengan :

1. Pre test tujuannya untuk mengetahui pengetahuan dan sikap WUS terhadap kanker serviks dan deteksi dini dengan IVA test

2. Melakukan komunikasi, informasi, edukasi(KIE) tentang kankerserviks dan IVA test 
3. Post testtujuannya untuk mengetahui pengetahuan dan sikap WUS terhadap kanker serviks dan deteksi dini dengan IVA test

4. Melakukan IVA test :

(a) Syarat mengikuti tes IVA

(b) sudah pernah melakukan hubungan seksual

(c) tidak sedang datang bulan/haid

(d) tidak sedang hamil

(e) 24 jam sebelumnya tidak melakukan hubungan seksual

5. Pelaksanaan skriningn tes IVA Untuk melaksanakan skrining dengan metode IVA, dibutuhkan tempat dan alat sebagai berikut:
a. ruangan tertutup, karena pasien diperiksa dengan posisi litotomi.
b. meja ginekologi/tempat tidur periksa yang memungkinkan pasien berada pada posisi litotomi.
c. terdapat sumber cahaya untuk melihat serviks
d. spekulum vagina
e. asam asetat (3-5\%)
f. swab-lidi berkapas
g. sarung tangan

Cara kerja:

1. Sebelum dilakukan pemeriksaan, pasien akan mendapat penjelasan mengenai prosedur yang akan dijalankan. Privasi dan kenyamanan sangat penting dalam pemeriksaan ini.

2. Pasien dibaringkan dengan posisi litotomi (berbaring dengan dengkul ditekuk dan kaki melebar).

3. Vagina akan dilihat secara visual apakah ada kelainan dengan bantuan pencahayaan yang cukup.

4. Spekulum (alat pelebar) akan dibasuh dengan air hangat dan dimasukkan ke vagina pasien secara tertutup, lalu dibuka untuk melihat leher rahim.

5. Bila terdapat banyak cairan di leher rahim, dipakai kapas steril basah untuk menyerapnya.

6. Dengan menggunakan pipet atau kapas, larutan asam asetat 3-5\% diteteskan ke leher rahim. Dalam waktu kurang lebih satu menit, reaksinya pada leher rahim sudah dapat dilihat.

7. Bila warna leher rahim berubah menjadi keputih-putihan, kemungkinan positif terdapat kanker. Asam asetat berfungsi menimbulkan dehidrasi sel yang membuat penggumpalan protein, sehingga sel kanker yang berkepadatan protein tinggi berubah warna menjadi putih.

8. Bila tidak didapatkan gambaran epitel putih padadaerah transformasi bearti hasilnya negatif.

\section{HASIL DAN PEMBAHASAN}

\subsection{Tahap Persiapan}

Kegiatan Pengabdian Masyarakat ini dipersiapkan mulai bulan Januari yang diawali dengan persiapan penyusunan proposal pengabdian masyarakat, seperti pencarian materi dan permintaan izin dari pimpinan. Sedangkan untuk tempat dan subjek yang akan dilakukan kegiatan ini dilakukan penjajakan yaitu penelusuran dan penelaahan tempat serta subjek yang akan diintervensi kemudian ditetapkan kader dan anak balita yang menjadi sasaran kegiatan. Pada kegiatan ini juga diajukan permintaan kesediaan menjadi mitra adalah Klinik Bersalin Sari dan Klinik Bersalin Sam di Kota Medan dan menyetujui untuk diadakan kegiatan pengabdian kepada masyarakat.

Perlengkapan yang digunakan untuk kegiatan pengabdian kepada masyarakat juga disiapkan di bulan ini yakni persiapan pembuatan spanduk, menggandakan kuesioner,menyaipkan alat dan bahan pemeriksaan IVA Test

\subsection{Pelaksanaan}

Kegiatan pengabdian masyarakat ini diawali dengan tahap persetujuan dilakukannya kegiatan ini olehKlinik Bersalin Sari dan Klinik Bersalin SAM yaitu pada tanggal 12 dan 21 Juni 
Diah Lestari. et.al. Deteksi Dini Kanker Servik Pada Wanita Usia Subur Dengan Inspeksi Visual Asam Asetat (Iva Test) Di Klinik Bersalin Kota Medan

2018.Sebelum WUS dilakukan pemeriksaan IVA Test terlebih dahulu dilakukan pre test dengan menggunakan kuesioner yang terdiri dari 19 pertanyaan tentang kanker serviks dan IVA Test. WUS diberi waktu menjawab sendiri selama 30 menit. Kemudian WUS diberi KIE dengan media laptop/slide dan leaflet. Selanjutnya WUS dilakukan pemeriksaan IVA Test. Setelah pemeriksaan IVA Test dilakukan post test dengan menggunakan kuesioner yang sama dengan pre test. Hasil wawancara dan kuesioner kemudian dianalisis menggunakan analisis data dependent $t$ test.

Tabel 1

Hasil pemeriksaan IVA Test Karakteristik WUS di Klinik Bersalin Medan $(n=40)$

\begin{tabular}{|c|c|c|}
\hline Variabel & $\mathrm{F}$ & $\%$ \\
\hline 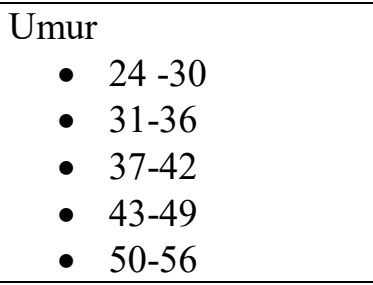 & $\begin{array}{c}7 \\
8 \\
13 \\
8 \\
4\end{array}$ & $\begin{array}{c}17.5 \\
20 \\
32.5 \\
20 \\
10\end{array}$ \\
\hline $\begin{aligned} \text { Suku } & \\
\text { - } & \text { Batak } \\
\text { - } & \text { Melayu } \\
\text { - } & \text { Jawa } \\
\text { - } & \text { Minang } \\
\text { - } & \text { Makasar } \\
\text { - } & \text { Banten } \\
\text { - } & \text { Aceh }\end{aligned}$ & $\begin{array}{c}13 \\
6 \\
10 \\
7 \\
2 \\
1 \\
1\end{array}$ & $\begin{array}{c}32.5 \\
15 \\
25 \\
17.5 \\
5 \\
2.5 \\
3.5\end{array}$ \\
\hline $\begin{aligned} \text { Agama } & \\
\text { - } & \text { Islam } \\
\text { - } & \text { Kristen }\end{aligned}$ & $\begin{array}{c}38 \\
2\end{array}$ & $\begin{array}{c}95 \\
5\end{array}$ \\
\hline $\begin{array}{ll}\text { Status pernikahan } \\
\text { - } & \text { Menikah } \\
& \text { Pertama / } \\
& \text { Sekali } \\
\text { - } & \text { Menikah kedua } \\
& \text { / Lebih }\end{array}$ & 31 & 77.5 \\
\hline $\begin{array}{l}\text { Pendidikan } \\
\text { - } \quad \text { Tamat SD } \\
\text { - } \quad \text { Tamat SMP }\end{array}$ & $\begin{array}{l}4 \\
4\end{array}$ & $\begin{array}{l}10 \\
10\end{array}$ \\
\hline
\end{tabular}

\begin{tabular}{|c|c|c|}
\hline $\begin{array}{l}\text { - Tamat } \\
\text { SMA/Diploma/ } \\
\text { sarjana }\end{array}$ & 32 & 80 \\
\hline $\begin{array}{l}\text { Pekerjaan responden } \\
\text { - } \text { PNS } \\
\text { - Karyawan } \\
\text { - } \text { Pedagang/wirau } \\
\text { - } \text { saha } \\
\text { - IRT }\end{array}$ & $\begin{array}{l}1 \\
6 \\
2\end{array}$ & $\begin{array}{c}2.5 \\
15 \\
5 \\
77.5\end{array}$ \\
\hline $\begin{array}{ll}\text { Pekerjaan suami: } \\
\text { - } \\
\text { - } & \text { Tidak bekerja } \\
\text { - } & \text { Karyawan } \\
\text { - } & \text { Pedagang/wirau } \\
& \text { saha } \\
\text { - } & \text { Supir }\end{array}$ & $\begin{array}{c}7 \\
3 \\
21 \\
8\end{array}$ & $\begin{array}{c}17.5 \\
7.5 \\
52.5 \\
20 \\
\\
2.5\end{array}$ \\
\hline $\begin{array}{cc}\text { Umur pertama menikah } \\
\text { - } & 15-20 \\
\text { - } & 21-25 \\
\text { - } & 26-30 \\
\text { - } & 31-35 \\
\text { - } & 36-40 \\
\text { - } & 41-45\end{array}$ & $\begin{array}{c}9 \\
11 \\
16 \\
2 \\
0 \\
2\end{array}$ & $\begin{array}{c}22.5 \\
27.5 \\
40 \\
5 \\
0 \\
5\end{array}$ \\
\hline $\begin{array}{l}\text { Merokok } \\
\text { • } \mathrm{Ya} \\
\text { - } \mathrm{Tidak}\end{array}$ & $\begin{array}{c}8 \\
32\end{array}$ & $\begin{array}{l}20 \\
80\end{array}$ \\
\hline
\end{tabular}

Berdasarkan tabel 1 diperoleh data mayoritas WUS berusia 26-30 tahun (40\%),suku batak (13\%),agama islam (95\%),menikah pertama kali (77.5\%),pendidikan SMA/diploma/sarjana (80\%),IRT (77.5\%),pekerjaan suami karyawan $(52.5 \%)$,umur pertama menikah 26-30 tahun(40\%) dan tidak merokok (80 $\%)$.

Tabel 2

Riwayat penggunaan alat kontrasepsi WUS di Klinik Bersalin Medan $(n=40)$

\begin{tabular}{|l|c|c|}
\hline \multicolumn{1}{|c|}{ Variabel } & F & $\%$ \\
\hline $\begin{array}{l}\text { Tidak } \\
\text { Pernah }\end{array}$ & 14 & 35.0 \\
\hline Pil & 1 & 2.5 \\
\hline Spiral & 3 & 7.5 \\
\hline Suntik & 17 & 42.5 \\
\hline Lainnya & 3 & 7.5 \\
\hline Lebih dari 1 & 2 & 5.0 \\
\hline
\end{tabular}


Diah Lestari. et.al. Deteksi Dini Kanker Servik Pada Wanita Usia Subur Dengan Inspeksi Visual Asam Asetat (Iva Test) Di Klinik Bersalin Kota Medan

Berdasarkan tabel 2 diperoleh data mayoritas WUS menggunakan alat kontrasepsi suntik (42.5\%)

Tabel 3

Riwayat obstetri WUS di Klinik Bersalin Medan (n=40)

\begin{tabular}{|c|c|c|}
\hline Variabel & $\mathrm{F}$ & $\%$ \\
\hline $\begin{aligned} & \text { Jumlah melahirkan } \\
& \text { - } 0 \\
& \text { - } 1 \\
& \text { - } 2 \\
& \text { - } 3 \\
& \text { - } 4 \\
& \text { - } 5\end{aligned}$ & $\begin{array}{c}7 \\
3 \\
17 \\
3 \\
7 \\
3\end{array}$ & $\begin{array}{c}17.5 \\
7.5 \\
42.5 \\
7.5 \\
17.5 \\
7.5\end{array}$ \\
\hline $\begin{array}{l}\text { Pernah periksa } \\
\text { - } \quad \text { Papsmear } \\
\text { - } \quad \text { Tidak pernah }\end{array}$ & $\begin{array}{c}8 \\
32\end{array}$ & $\begin{array}{l}20 \\
80\end{array}$ \\
\hline $\begin{array}{l}\text { Saudara kandung sakit } \\
\text { kanker } \\
\text { - Ya } \\
\text { - Tidak }\end{array}$ & $\begin{array}{l}10 \\
30\end{array}$ & $\begin{array}{l}25 \\
75\end{array}$ \\
\hline $\begin{array}{l}\text { Siapa yang sakit } \\
\text { - Tidak ada } \\
\text { - Kakak } \\
\text { - Adek } \\
\text { - Anak } \\
\text { - Ibu }\end{array}$ & $\begin{array}{l}30 \\
2 \\
5 \\
2 \\
1\end{array}$ & $\begin{array}{c}75 \\
5 \\
12.5 \\
5 \\
2.5\end{array}$ \\
\hline $\begin{array}{cl}\text { Sakit apa } \\
\text { - } & \text { Tidak ada } \\
\text { - } & \text { Kanker } \\
& \text { payudara } \\
\text { - } & \text { Mioma } \\
\text { - Hemofilia } \\
\text { - } \\
\text { Kanker rahim } \\
\end{array}$ & $\begin{array}{l}30 \\
4 \\
\\
2 \\
2 \\
2\end{array}$ & $\begin{array}{l}75 \\
10 \\
\\
5 \\
5 \\
5\end{array}$ \\
\hline $\begin{array}{c}\text { Keluhan kandungan } \\
\text { - Ya } \\
\text { • Tidak }\end{array}$ & $\begin{array}{l}11 \\
29\end{array}$ & $\begin{array}{l}27.5 \\
72.5\end{array}$ \\
\hline
\end{tabular}

\begin{tabular}{|c|c|c|}
\hline $\begin{array}{l}\text { Keluhan } \\
\text { keputihan } \\
\text { - Ya } \\
\text { - Tidak }\end{array}$ & $\begin{array}{l}14 \\
26\end{array}$ & $\begin{array}{l}35 \\
65\end{array}$ \\
\hline $\begin{array}{l}\text { Sakit diperut } \\
\text { bawah/panggul } \\
\text { - Ya } \\
\text { - Tidak }\end{array}$ & $\begin{array}{l}18 \\
22\end{array}$ & $\begin{array}{l}30 \\
70\end{array}$ \\
\hline $\begin{array}{l}\text { Pendarahan } \\
\text { bersenggama } \\
\text { - Ya } \\
\text { - Tidak }\end{array}$ & $\begin{array}{c}4 \\
36\end{array}$ & $\begin{array}{l}10 \\
90\end{array}$ \\
\hline $\begin{array}{l}\text { Haid } \quad \text { perdarahan } \\
\text { tidak teratur } \\
\qquad \quad \text { Ya } \\
\text { - Tidak }\end{array}$ & $\begin{array}{l}18 \\
22\end{array}$ & $\begin{array}{l}45 \\
55\end{array}$ \\
\hline
\end{tabular}

Berdasarkan tabel 3 diperoleh data riwayat obstetri mayoritas WUS melahirkan 2 kali (42.5\%),tidak pernah periksa $(80 \%)$,tidak ada saudara yang sakit $(75 \%)$,kanker payudara $(10 \%)$,tidak banyak keputihan (65\%),tidak ada sakit di bawah perut $(70 \%)$, tidak ada perdarahan saat bersenggama $(90 \%)$ dan tidak mengalami haid tidak teratur (55\%).

\section{Tabel 4}

Hasil IVA Test pada WUS di Klinik Bersalin Medan $(n=40)$

\begin{tabular}{|l|c|c|}
\hline \multicolumn{1}{|c|}{ Variabel } & $\mathrm{F}$ & $\%$ \\
\hline Negatif & 32 & 80 \\
\hline Radang & 7 & 17.5 \\
\hline Positif & 1 & 2.5 \\
\hline
\end{tabular}

Berdasarkan table 4 diperoleh data mayoritas hasil IVA Test WUS adalah negatif $(80 \%)$,radang $(17,5)$ dan positif (2.5). 
Diah Lestari. et.al. Deteksi Dini Kanker Servik Pada Wanita Usia Subur Dengan Inspeksi Visual Asam Asetat (Iva Test) Di Klinik Bersalin Kota Medan

Tabel 5

Kesioner pengetahuan WUS tentang kanker serviks dan IVA TEST di Klinik Bersalin Medan $(\mathbf{n}=\mathbf{4 0})$

\begin{tabular}{|c|l|c|c|c|c|c|c|c|c|}
\hline \multirow{2}{*}{ No } & \multirow{2}{*}{ Pertanyaan } & \multicolumn{3}{c|}{ Pre test } & \multicolumn{5}{c|}{ Post test } \\
\cline { 3 - 10 } & & \multicolumn{2}{|c|}{ Benar } & \multicolumn{2}{c|}{ Salah } & \multicolumn{3}{c|}{ Benar } & \multicolumn{2}{c|}{ Salah } \\
\cline { 3 - 10 } & & $\mathrm{f}$ & $\%$ & $\mathrm{f}$ & $\%$ & $\mathrm{f}$ & $\%$ & $\mathrm{f}$ & $\%$ \\
\hline & Pengetahuan tentang kanker serviks & & & & & & & & \\
\hline 1 & Defenisi kanker Rahim (serviks) & 34 & 85 & 6 & 15 & 24 & 60 & 16 & 40 \\
\hline 2 & Etiologi kanker rahim & 20 & 50 & 20 & 50 & 28 & 70 & 12 & 30 \\
\hline 3 & Tanda dan gejala kanker rahim & 31 & 77.5 & 9 & 22.5 & 34 & 85 & 6 & 15 \\
\hline 4 & Klasifikasi stadium kanker rahim & 6 & 15 & 34 & 85 & 17 & 42.5 & 23 & 37.5 \\
\hline 5 & Faktor resiko kanker rahim & 14 & 35 & 26 & 65 & 21 & 52.5 & 19 & 47.5 \\
\hline 6 & $\begin{array}{l}\text { Wanita yang merokok lebih beresiko } \\
\text { terkena kanker serviks }\end{array}$ & 28 & 70 & 12 & 30 & 23 & 57.5 & 17 & 42.5 \\
\hline 7 & $\begin{array}{l}\text { Berganti gnati pasangan } \\
\text { memperbesar resiko terkena kanker } \\
\text { serviks }\end{array}$ & 30 & 75 & 10 & 25 & 32 & 80 & 8 & 20 \\
\hline 8 & $\begin{array}{l}\text { Usia yang rentan terserang kanker } \\
\text { serviks }\end{array}$ & 23 & 57.5 & 17 & 42.5 & 24 & 60 & 16 & 40 \\
\hline 9 & Proses terjadinya kanker serviks & 29 & 72.5 & 11 & 27.5 & 33 & 82.5 & 7 & 17.5 \\
\hline 10 & Stadium kanker serviks & 33 & 82.5 & 7 & 17.5 & 36 & 90 & 4 & 10 \\
\hline & $\begin{array}{l}\text { Pengetahuan tentang pencegahan } \\
\text { kanker serviks }\end{array}$ & & & & & & & \\
\hline 11 & Tidak berganti-ganti pasangan & 37 & 92.5 & 3 & 7.5 & 38 & 95 & 2 & 5 \\
\hline 12 & Banyak anak & 33 & 82.5 & 7 & 17.5 & 37 & 92.5 & 3 & 7.5 \\
\hline 13 & Terlambat periksa & 37 & 92.5 & 3 & 7.5 & 34 & 85 & 6 & 15 \\
\hline 14 & Vaksinasi HPV & 36 & 90 & 4 & 10 & 34 & 85 & 6 & 15 \\
\hline 15 & $\begin{array}{l}\text { Penggunaan pembersih vagina yang } \\
\text { mengandung antiseptik }\end{array}$ & 25 & 62.5 & 15 & 37.5 & 31 & 77.5 & 9 & 22.5 \\
\hline 16 & Kebersihan alat kelamin & 38 & 95 & 2 & 5 & 36 & 90 & 4 & 10 \\
\hline 17 & Perlunya IVA Test & 34 & 85 & 6 & 15 & 34 & 85 & 6 & 15 \\
\hline 18 & Tujuan IVA Test & 37 & 92.5 & 3 & 7.5 & 37 & 92.5 & 3 & 7.5 \\
\hline 19 & Manfaat IVA Test & 18 & 45 & 22 & 55 & 17 & 42.5 & 23 & 57.5 \\
\hline
\end{tabular}

Tabel 6

Perbedaan pengetahuan WUS sebelum dan sesudah diberi pendidikan kesehatan tentang kanker serviks dan IVA Test di Klinik Bersalin $(n=40)$

\begin{tabular}{|c|c|c|c|c|}
\hline Variabel & Mean & SD & $\begin{array}{c}\text { Beda } \\
\text { mean }\end{array}$ & $\begin{array}{c}\text { Nilai } \\
\mathrm{P}\end{array}$ \\
\hline $\begin{array}{r}\text { Pengetahuan } \\
-\begin{array}{c}\text { Pre } \\
\text { test }\end{array}\end{array}$ & 13.58 & 3.012 & 0.725 & 0.016 \\
$-\begin{array}{c}\text { Post } \\
\text { test }\end{array}$ & & 3.275 & & \\
\hline
\end{tabular}

Berdasarkan tabel 6 diperoleh data pengetahuan WUS sebelum diberi Komunikasi Edukasi Informasi (KIE) tentang kanker serviks dan IVA Test ratarata $=13.58, \mathrm{SD}=3.012$ dan sesudah diberi pendidikan kesehatan rata - rata $=14.30, \mathrm{SD}$ $=3.275$. Hasil uji statistik diperoleh beda mean $=0.725$ dan nilai $\mathrm{P}=0,016$, maka dapat disimpulkan ada pengaruh yang signifikan KIE terhadap pengetahuan WUS tentang kanker serviks dan IVA Test. 
Diah Lestari. et.al. Deteksi Dini Kanker Servik Pada Wanita Usia Subur Dengan Inspeksi Visual Asam Asetat (Iva Test) Di Klinik Bersalin Kota Medan

\section{KESIMPULAN}

Kegiatan pemeriksaan IVA ;Test dan KIE (komunikasi Edukasi dan Informasi) yang dilakukan kepada 40 WUS di Klinik Bersalin Sari dan Klinik Bersalin Sam mendapat respon yang positif dari masyarakat khususnya WUS. Dari hasil pemeriksaan ditemukan negatif (80\%),radang (17,5\%) dan positif (2.5\%).

\section{UCAPAN TERIMA KASIH}

Kegiatan pengabdian masyarakat yang telah dilaksanakan telah dapat diselesaikan dengan dan didapat hasil yang diharapkan dapat diadopsi oleh masyarakat. Dalam pelaksanaan kegiatan ini, tim peneliti banyak mendapat bantuan dari bebagai kalangan, sehingga kegiatan pengabdian ini dapat terlaksana. Sehubungan dengan hal tersebut, tim peneliti mengucapkan terima kasih kepada LPPM USU yang telah membiayai kegiatan ini.

\section{DAFTAR PUSTAKA}

Aziz M. F., (2006). Buku Acuan Nasional Onkologi Ginekologi. Jakarta: Yayasan Bina PustakaSarwono Prawirohardjo. 112: 274; 2006

Juandai.D., Kesuma.H.,(2015). Pemeriksaan Metode IVA (Inspeksi Visual Asam Asetat) untuk Pencegahan Kanker
Serviks.Jakarta: Jurnal Kedokteran dan Kesehatan, Volume2, No. 2, April 2015: 169-174

Prandana.D.P,Rusda.M. (2013).Pasien kanker serviks diRS.H.Adam Malik Medan 2011.e journal Fakultas kedokteran USU.Vol.1.nomor .2.

Ropitasari.,Soetrisno.,Mulyani.S.,Saddhono.K. , (2014). Deteksi dini kanker leher rahim melalui tes IVA di PUSKESMAS JATEN II Kabupaten Karanganyar. Jurnal fakultas kedokteran Universitas Sebelas Maret;VOL 3 No 1 Nov 2014

Aziz M. F, dkk. Buku Acuan Nasional Onkologi Ginekologi. Jakarta: Yayasan Bina Pustaka

Sarwono Prawirohardjo. 112: 274; 2006

Depkes RI. Modul Pelatihan Deteksi Dini KankerPayudara dan Kanker Leher Rahim; 2010

Rahmadyanti .,(2015). Pengetahuan WUS tentang deteksi dini kanker serviks dengan metode IVA test di Cipinagn Besar Utara.Jatinegara. Jurnal Permata MedikaPasien Kanker. Volume 4 No 1, Juli 2015.

Wiyono S, Iskandar M, dkk..Inspeksi VisualAsam Asetat (IVA) Untuk Deteksi Dini Lesi PraKanker Serviks.www.jurnal MediaMediasiana Indonesia.Volume 43.Nomor 3;2008.116-120. 